\title{
Is the use of mobile phones good for your neck? Text neck syndrome as an awareness of the existing threat - literature review
}

\author{
Czy używanie telefonów komórkowych jest dobre dla twojej szyi? \\ Syndrom szyi SMS-owej jako świadomość istniejącego zagrożenia. \\ Przegląd literatury
}

\author{
Monika Gałczyk ${ }^{1, A-B, D-E \oplus}$, Wojciech Kułak ${ }^{2, F} \oplus$, Anna Zalewska ${ }^{1, B} \oplus$ \\ 1 State University of Applied Sciences, Łomża, Poland \\ ${ }^{2}$ Department of Paediatric Rehabilitation and Centre of Early Support for Handicapped Children 'Give a chance', \\ Białystok, Poland \\ A - Research concept and design, B - Collection and/or assembly of data, C - Data analysis and interpretation, \\ $D$ - Writing the article, E-Critical revision of the article, F- Final approval of article
}

Gałczyk M, Kułak W, Zalewska A. Is the use of mobile phones good for your neck? Text neck syndrome as an awareness of the existing threat - literature review. Med Og Nauk Zdr. 2020; 26(3): 240-243. doi: 10.26444/monz/126848

\begin{abstract}
Introduction. SMS neck syndrome is a problem that threatens the physical and mental health of modern mobile phone users. It is difficult for today's population to function without mobile devices, therefore the problem of using mobile phones concerns many aspects of a social, health and psychological nature. People who use phones excessively potentially increase the risk of developing musculoskeletal problems. Using smartphones contributes to incorrect body posture, which in turn causes neck and back pain.

Objective. The aim of the study based on a literature review was to present the threats arising from the use of mobile phones, and to identify the main health problems of mobile device users.

Brief description of the state of knowledge. The literature review included scientific literature published in the period between 2011-2019. The resources of three bibliographic databases were searched: Medline (Medical Literature Analysis and Retrieval System Online), Web of Science, and PubMed. On analyzing the literature in the field of psychology, pedagogy and sociology, it can be seen that in Poland there is a lack of intercultural screening tools, which would be quick and easy method to identify groups of young people at risk by using a mobile phone, who by engaging in this activity experience various problems of social, health or mental nature.

Conclusions. This literature review confirms the need for public health education programmes to inform people about the physical dangers of excessive smartphone use. Smartphone addiction can significantly impair the function and cause pain of the cervical spine.
\end{abstract}

\section{Key words}

SMS neck, cell phone, phonholism, computer vision syndrome

Address for correspondence: Monika Gałczyk, State University of Applied Sciences, Łomża, Poland

E-mail: monikagalczyk@onet.eu

Received: 08.05.2020; accepted: 26.08.2020; first published: 04.09.2020

\begin{abstract}
Streszczenie
Wprowadzenie. Syndrom szyi SMS-owej stanowi problem zagrażający zdrowiu fizycznemu i psychicznemu współczesnych użytkowników telefonów komórkowych. Dzisiejszej populacji trudno jest funkcjonować bez urządzeń mobilnych, stąd kwestia używania telefonów komórkowych dotyczy wielu aspektów natury społecznej, zdrowotnej i psychicznej. U osób nadmiernie używających telefonu potencjalnie wzrasta ryzyko pojawienia się problemów układu mięśniowo-szkieletowego. Korzystanie ze smartfonów przyczynia się do przyjmowania nieprawidłowej postawy, która z kolei powoduje dolegliwości bólowe szyi i pleców.

Cel pracy. Celem pracy było przedstawienie zagrożeń wynikających z użytkowania telefonów komórkowych oraz identyfikacja głównych problemów zdrowotnych użytkowników urządzeń mobilnych na podstawie przeglądu literatury.

Skrócony opis stanu wiedzy. Przegląd piśmiennictwa obejmował literaturę naukową opublikowaną w okresie między 2011 a 2019 rokiem. Przeszukano zasoby trzech baz bibliograficznych: Medline (Medical Literature Analysis and Retrieval System Online), Web of Science oraz PubMed. Analizując literaturę z dziedziny psychologii, pedagogii i socjologii, można zauważyć, że w Polsce brak jest narzędzi do badań przesiewowych o wymiarze międzykulturowym, dzięki którym szybko i łatwo można byłoby identyfikować grupy młodzieży ryzykownie używającej telefonów komórkowych, a przez to doświadczającej przeróżnych problemów natury społecznej, zdrowotnej czy psychicznej.

Podsumowanie. Dokonana analiza literatury potwierdza potrzebę wdrożenia programów edukacyjnych w zakresie zdrowia publicznego w celu informowania społeczeństwa o fizycznych zagrożeniach związanych z nadmiernym używaniem smartfonów. Uzależnienie od telefonów może powodować dolegliwości i znaczne upośledzenie funkcji odcinka szyjnego kręgosłupa.
\end{abstract}

\section{Słowa kluczowe}

telefon komórkowy, fonoholizm, szyja SMS-owa, zespół widzenia komputerowego 


\section{INTRODUCTION}

In the contemporary world it is difficult to imagine life without any access to the Internet, especially mobile internet Smartphones which are used for voice and text messages, as well as for entertainment (playing games, watching movies, etc.). All this has become possible mainly due to the fact that a modern smartphone is not only a telephone, but is also even considered a miniature computer. Therefore, many people say that it is not possible to function fully and properly in today's world without using mobile devices' [1].

Regardless of the age of users, the mobile phone has become an inseparable element of a modern everyday life. Younger and younger children have joined the group of smartphone users. Cell phone users usually have their smartphones superglued to their hands, and even while asleep, they have their phones next to the bed or under the pillow [2,3].

The smartphone, one of the most popular devices among teenagers, offers their users a wide variety of functions, such as multimedia players, compact digital cameras, access to e-mail messages, GPS navigation and high resolution touch screens [4]. The progress in mobile technological solutions contributes to frequent use and dependence on cell phones. With the increase in the use of smartphones, the potential risk of musculoskeletal problems has been reported $[4,5]$.

Analyzing the development of mobile telephony, it should be highlighted that the problematic exploitation and overuse of cell phones or smartphones will be more and more common and initiated much earlier among the younger generation $[6,7]$.

Most tasks on smartphones require the user to look sharply downwards or reach out in front of them to read the screen, so the head tilts downwards causing the upper thoracic spine to curve backwards excessively, or it shifts forward, increasing the lordosis of the lower cervical spine.

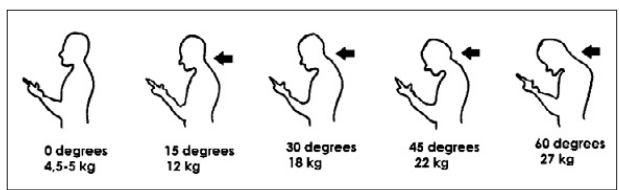

Figure 1. The level of load on the spine depending on the degree of flexion of the cervical segment when using a smartphone

The anterior head posture is one of the commonly recognized improper positions in the sagittal plane. It has been pointed out that this posture may contribute to the onset and fixation of neck and back pain syndromes, with further loss of cervical spine extension (Burgess-Limerick, Plooy and Ankrum, 1998; McEvoy and Grimmer, 2005). Head anterior posture is determined by a dynamic combination of everyday life factors, inlcuding computer use [8]. The abnormal head and neck posture correlates with chronic musculoskeletal pain.

\section{OBJECTIVE}

The aim of the study was to present the threats arising from the use of mobile phones, and to identify the main health problems of mobile device users based on a literature review.

\section{DESCRIPTION OF THE STATE OF KNOWLEDGE}

The role of a mobile phone in the functioning of children and adolescents. The modern life of the younger generation is mainly associated with the use of new digital technologies, primarily mobile phones. Research shows that children and adolescence use this device on a daily basis, and the intensity of its use and the age of initiation of use causes anxiety for parents, tutors, therapists and doctors. The fears are well justified because the problematic nature of using a mobile phone is increasingly being experienced.

In the school population, it is crucial to constantly diagnose and monitor such behaviours that can become a form of addiction that disturbs the functioning of the young generation in a family, school or peer environment. Analyzing the literature in the field of psychology, pedagogy and sociology one can notice that in Poland there is a lack of intercultural screening tools, through which it would be possible to quickly and easily identify the groups of young people who use mobile phones in a risky way [9]. While engaging in this activity, adolescence and children experience various problems of a social, health or mental nature. In the contemporary world, changes in technology are rapidly progressing, and we are provided with more and more modern electronic gadgets that substitute numerous everyday objects, such as: an alarm clock, a watch, a notebook. The phone reminds one of important events, and thanks to the Internet connection allows constant access to information and an unlimited sphere of entertainment, as well as enabling contact with peers or providing access to social networks.

It should also be noted that often parents themselves, not wanting to lead to exclusion from the peer environment, purchase this type of equipment, often without being aware of the risks that may occur. Youths and children, observing the behaviour of their parents who are often a model for them, are increasingly using their phones not only to contact their peers - imitating their parents - but also to watch movies, social channels, or just play games which are more and more widely available on these devices. The desire and the fact of having new phone models somehow determine the social position of young people. This also has consequences in the form of the need to provide funds for the new needs of children. The consequence of this is the need for parents to work longer, and thus devote less time to their children. This, in turn, leads to neglect in the interpersonal relationships of children and parents, as well as with peer environments. It also leads to disturbances in supervision over the behaviour of children, and indirectly tolerating a bad lifestyle by children abandoning physical activity, such as playing sports in the form of organized extracurricular activities in a peer environment or with parents themselves.

Available research shows that young people use mobile phones more often than adults, and the percentage of those abusing it is in the range of $5.57 \%-33 \%$ [7]. In addition to the widespread use of smartphones by children and young people, another important element is the place and the way it is used. Polish adolescence use the phone at school during classes $(60 \%)$, writing tests (18\%), as well as during breaks, meals (44\%) and talking to others (25\%). There are also those who use it while watching a movie at the cinema (28\%) or in church (8\%). Recent studies denote an even greater intensity and prevalence of mobile phone use in the above-mentioned situations [9]. In addition, analyzing the existing phenomenon, 
the significant impact of using a mobile phone can be seen on the daily life of the young generation. For this group, it is crucial to make quick, short contact (this is seen as an advantage by $67 \%$ of respondents), and the attractiveness of the message (emphasised by $67 \%$ and $72 \%$, respectively). Additionally, telephone transmission or texting provide teenagers with the opportunity to communicate with others, regardless of the time and place ( $95 \%$ consider it a huge advantage).

Mobile phone use, apart from its benefits, also has some disadvantages, e.g. the very important threat of adopting an improper body posture, which can lead to a disruption in the development of the normal skeletal system affecting the young generation [9]. According to qualitative research conducted in 2015-2016, young people themselves indicate such effects as fatigue, apathetic mood, a problem with the performance of daily duties, trembling hands, and even aggression [10]. The question bothering researchers is whether young people can go without a cell phone all day. Most teenagers say "yes, it's not difficult"; "yes, because I have a strong will"; "yes, because I prefer to spend time with loved ones", etc., but there are also other honest answers showing this problem: "no, why should I be bored"; "no, because I have to be in touch with friends" or running away from justifying their point of view with the words "I don't know"; "No, because I need to know what is happening in the world of social networking" [11].

Mostly, the problem of phonholism among young people concerns turning-off the mobile phone at bedtime. Most young people do not see such a need and do not do so. Adolescence, despite media education, are unaware of the consequences of holding the phone to their heads at night. When the brain is at rest, it is exposed to electromagnetic radiation harmful to the nervous system and physical and mental health [12].

Phonoholism is considered a serious addiction and a civilization disease of the 21st century which affects especially young people who are influenced by a mobile phone to the extent that it becomes indispensable everywhere and in every situation [13]. Adolescents do not realize that how they function today will affect their future lives. It is important here and now, without thinking about the consequences. Parents play an important role here, because they should control how long and for what purpose their child can use a mobile phone [14]. Specialist care and intervention as well as therapy is important to develop healthy habits for using the smartphone. If an individual controls his/her behaviour, is aware of the consequences and tries to prevent them, then the mobile phone will not pose a threat, because it will be a mean to contact with loved ones and a tool for communication and information [15].

Year by year, the percentage of mobile phone addiction is increasing among the younger generation, thus making children and young people aware of the dangers of excessive use of a cell phone will help to prevent the occurrence of text neck syndrome. Adolescents are unaware of text neck syndrome and have no knowledge of measures to prevent related musculoskeletal problems [16].

The cervical spine is a continuous, coordinated network of bones, muscles and joints which allow head movements and protect the spinal cord and initial parts of peripheral nerves. Irritation of these neuronal pathways, e.g. by a long-lasting improper head position while using mobile phone, leads to pain which, in turn, can cause problems in the muscular and skeletal systems, mainly in the cervical spine. The term 'text neck syndrome' was first used by the American therapist Dean L. Fishman [17].

By definition, text neck syndrome is a repetitive stress injury and prolonged pain caused by watching and writing SMS on mobile devices in the same position for a long time. Spending a large amount of time using the phone leads to the appearance of harmful symptoms, such as neck pain, upper back pain, shoulder pain, chronic headaches and an increase in curvature of the spine. When using a cell phone, users usually adopt an improper body posture by tilting their head forward. Research in Thailand shows that the 'text neck syndrome' has become a global epidemic affecting a large proportion of the population. It is an increasing health problem. If the 'text neck syndrome' is ignored and preventive measures are not taken, it can lead to serious, permanent damage. An untreated 'text neck' can cause inflammation of the ligaments, muscles and nerves of the neck, leading to permanent musculoskeletal changes. This can cause serious damage, such as spinal degeneration, arthritis, disc compressions, disc herniation, etc. The main goal of modern researchers is to make the population aware that 'text neck syndrome' is a common and significant health problem [16] which is underestimated worldwide.

In Mumbai and Pura in Maharashtra from August 2017 to February 2018 a research was conducted to investigate young Indian people's knowledge concerning the "text neck syndrome" and preventive measures. The study involved 311 mobile phone users aged 18 to 24 years. The main purpose of the research was to increase population awareness, regarding the „text neck syndrome” and to expand knowledge about preventive measures. The results of the study showed that $65 \%$ of the surveyed population were not aware of the "text neck syndrome", $27 \%$ heard about it, but did not know what it was, and only $8 \%$ were of an existing health problem. The results of the study showed that $65 \%$ of the surveyed population were not aware of the "text neck syndrome", $27 \%$ heard about it, but did not know what it was, and only $8 \%$ were aware of an existing health problem.

The results of the conducted research showed that $11 \%$ of respondents used their phones for 1 hour, $42 \%$ for $2-4$ hours a day and $27 \%$ of them spend $4-6$ hours a day on the phone. The remaining $20 \%$ of the questioned population uses the phone over 6 hours a day [18].

Studies conducted in Korea, among 292 people aged $21.42 \pm 1.57$ years, from various non-medical institutions, confirm a positive relationship between the hours of using a mobile phone and subjective problems of the musculoskeletal system [19].

The most often the body posture adopted when using a smartphone is bending the cervical spine with a bowed head and rounding the back. If this posture is maintained for a long time, the center of gravity is transferred. The resulting imbalance causes muscle contracture and as a consequence neck, shoulder and upper back pain. The lower the head is tilted, the greater the load on the cervical spine. The human head weighs $4-5 \mathrm{~kg}$ in upright position. When texting, the head tilt increases, increasing at the same time the weight of the head in relation to the spine. Maximum inclination up to 60 degrees, gives a load of $27 \mathrm{~kg}$ for the spine [18].

Improper body position maintained for years leads to degenerative changes in the cervical region. Unfortunatelly awareness about the "text neck syndrome” is not enough [20]. 
The issue of, text neck" is also a serious problem among children because their heads are larger in relation to their bodies than in adults. Children are more likely to suffer from,,text neck" syndrome, considering their inclination to use cell phones. Serious and permanent damage to an untreated disorder can be very similar to a set of repetitive stress or strain related injuries [21].

The problem of the general abuse of smart devices, is reflected in studies that found that US citizens looked at their smartphones to surf the Internet, communicate and socialize on average three hours a day [22]. Asian investigation indicated that almost everyone has a mobile phone (97.4\%) and spend about four hours a day it. A crosssectional study was conducted on 78 healthy students with an average age of $21.3 \pm 1.7$ years ( 39 women and 39 men) from King Saud University. Cell phone addiction caused cervical disability among smartphone users, which can be associated with frequent flexion posture that changes the natural curvature of the cervical spine and increases the strain on the cervical spine, leading to irritation and spasm in surrounding skeletal structures and ligaments [23]. In the study performed in Pakistan, the Smartphone Addiction Scale (SAS) and the fitness index for back pain (NDI) were implemented in order to measure smartphone addiction and any abnormal symptoms of neck functioning. The results of the study showed that everyone used the smartphone for several hours a day and there was a clear relationship between smartphone addiction and various degrees of neck problems among participants. Such excessive use of smartphones can lead to habitual repetitive and continuous head and neck movements toward the screen throughout the day. The movements are associated with a high risk of chronic neck pain and may explain the strong relationship between SAS and NDI results [24].

\section{CONCLUSIONS}

This review of the literature confirms the need for public health education programmes to inform people about the physical dangers of excessive smartphone use. Smartphone addiction can cause significant impairment of the cervical spine, andiImproper body posture associated with the use of smartphones can cause neck function impairment. The users at the forefront of technology should try to reduce the amount of time spent using the smartphone, as well as try to maintain proper body posture while using it.

\section{REFERENCES}

1. Pawelec L. Dziecko w wieku przedszkolnym jako użytkownik urządzeń mobilnych (telefon, tablet, smartfon). Acta Scientifica Academiae Ostroviensis. Sectio A, Nauk Hum Społ Tech. 2017; 10(2):7-17.
2. Czerski W.M. Zjawisko uzależnienia od smartfonu dzieci i młodzieży w świetle wybranej literatury. Edukacja-Informatyka-Technika 2019; 2(28): 257-263. DOI: 10.15584/eti.2019.2.38, s. 257-263.

3. Duda M, Czerski WM. Nowe uzależnienia XXI wieku jako problem zdrowotny. W: Zbroszczyk D (red.), Wybrane problemy i zagrożenia bezpieczeństwa człowieka, Radom: Wyd. UTH, 2018:9-29.

4. Demirci K, Akgonul M, Akpinar A. Relatioship of smartphone use severity with sleep quality, depression and anxiety in university students. J Behav Add. 2015; 4(2): 85-92. DOI: 10.1556/2006.4.2015.010.

5. Nejati P, Lotfian S, Moezy A, Nejati M. The Relationship of Forward Head Posture and Rounded Shoulders with Neck Pain in Iranian Office Workers. Med J Islam Repub Iran 2014; 28:26.

6. Lopez-Fernandez O, Freixa-Blanxart M, Honrubia-Serrano ML. The Problematic Internet Entertainment Use Scale for Adolescents: Prevalence of Problem Internet Use in Spanish High School Students „CyberPsychology, Behavior \& Social Networking” 2013;16 (2):108-118.

7. Lopez-Fernandez O, Honrubia-Serrano L, Freixa-Blanxart M, Gibson W. Prevalence of Problematic MobilePhone Use in British Adolescents „CyberPsychology, Behavior \& Social Networking” 2014; 17(2):91-98 https://doi.org/10.1089/cyber.2012.0260

8. Straker LM, Smith AJ, Bear N. Neck/shoulder pain, habitual spinal posture and computer use in adolescents: the importance of gender. J Econ. 2011;54: 539-546.

9. Krzyżak-Szymańska E. Telefon komórkowy w codziennym życiu młodzieży- gadżet współczesności czy źródło nałogu? Dylematy i wyzwania XXI wieku ujęcie interdyscyplinarne, red. W. Kądziołka. Stalowa Wola 2014:69-90.

10.Dębski M. Nałogowe korzystanie z telefonów komórkowych. Szczegółowa charakterystyka zjawiska fonoholizmu w Polsce. Raport z badań - skrót. Fundacja Dbam o Mój Z@sięg,Gdynia,2018:18.

11. Sarzała D, Jędrzejko MZ. Telephone zombie. Zjawisko fonoholizmu wśród uczniów jako nowa forma cyberzaburzeń [w:] Pedagogika i profilaktyka społeczna, Oficyna Wydawnicza von Velke \& Oficyna Wydawnicza ASPRA, Warszawa,2018;85:75-103.

12. Spitzer M. Cyberchoroby. Jak cyfrowe życie rujnuje nasze zdrowie? Dobra Literatura, Słupsk, 2016:116-120.

13. Karaś A. Fonoholizm - choroba współczesnej młodzieży. Doniesienie z badań, Medyczne i behawioralne uwarunkowania stanu zdrowia pod red. W. Truszkowskiego. Olsztyn, 2019: 44-52.

14. Mysior R. Fonoholizm w kręgu uzależnienia. Problemy opiekuńczowychowawcze: $2015 ; 55(10): 28-33$.

15. Goetz M. Fonoholizm - kiedy telefon staje się pułapką. Głos Pedagogiczny 2015; (71): 50-56.

16. Samani PP, Athavale NA, Shyam A, Sancheti PK. Awareness of text neck syndrome in young-adult population. IJCMPH 2018; 5(8): 3335-3339. DOI: http://dx.doi.org/10.18203/2394-6040.ijcmph20183057

17. Neupane S, Ali UI, Mathew A. Text Neck Syndrome-Systematic Review. IJIR 2017; 3(7): 141-8.

18. Hansraj KK. Assessment of stresses in the cervical spine caused by posture and position of the head. Surg Technol Int. 2014; 25:277-9.

19. Kim HJ, Kim JS. The relationship between smartphone use and subjective musculoskeletal symptoms and university students. J Phys Ther Sci. 2015; 27(3): 575-9 DOI: 10.1589/jpts.27.575

20. Sunil Neupane, Ifthikar Ali U T, Mathew A. Text Neck Syndrome Systematic Review. Imperial J Interdysc Res. 2017;3(7):141-148.

21. Rosenberg S. Cell Phones and Children: Follow the Precautionary Road. Pediatr Nurs. 2013; 39(2):65-70.

22. Gold JE, Driban JB, Thomas N, Chakravarty T, Channell V, Komaroff E. Postures, typing strategies and gender differences in mobile device usage: An observational study. Appl Ergon. 2012;43(2):408-412. DOI: 10.1016/j.apergo.2011.06.015.

23. Abdullah Farooq Khan, Syed Faraz Ul Hassan Shah Gillani, Ahsan Farooq Khan, Alia Wahid. Are You Suffering Pain Neck Due to Smart Phone Text Neck Syndrome. PJMHS 2018; 12(3): 1095-1097.

24. AlAbdulwahab SS, Kachanathu SJ, AlMotairi MS. Smartphone use addiction can cause neck disability. Musculoskeletal Care. 2017; 15(1):10-12. DOI:10.1002/msc. 1170 